Gabin (Purdue University). In evaluating the memories of black and white women workers in the Great Lakes region concerning their survival and occupational strategies during the Depression, Helmbold argued that racial differences outweighed gender similarities between women. Helmbold further cautioned labor historians who focus on women's work patterns to focus on service sector employment as well as industrial employment.

Helmbold's remarks resonated with one of the final panels of the conference, "Detroit Remembers," in which a fiery debate about racism in the United Auto Workers (UAW) underscored the challenge of addressing race in both labor organizing and historiography. Several of the panelists explored the racial complexity of Detroit's labor history. Kevin Boyle (University of Massachusetts) emphasized that understanding the power of race and racism was key to the labor history of Detroit. Reinforcing the conference's concern with community, Heather Thompson (University of Michigan) linked race to labor and urban history. The history of a recomposed Detroit after World War Two was, Thompson emphasized, a history of labor decline and urban decay. Copanelist Tom Sugrue (University of Pennsylvania) also discussed Detroit's downward spiral and how anticommunism and neoclassical economics had helped remove issues of economic inequality from organized labor's agenda. However, reflecting the field of labor history itself, most of the other discussants focused on UAW history as representing Detroit's labor history, thus ignoring the service sector and workers' communities outside of UAW confines.

As workers address the economic transformations of recent decades, understanding how difference has often been translated into division is important. The conference provided an excellent forum for exploration of working-class memory and the widening concerns of labor history.

\title{
The Fight for America's Future: A Teach-In with the Labor
}

\section{Movement}

\author{
Teal Rothschild and William Milberg \\ New School for Social Research
}

Dan Rosenberg

Adelphi University

\begin{abstract}
An enthusiastic and mostly optimistic gathering of scholars and labor activists met at Columbia University in New York on October 3 and 4, 1996, in an effort to revitalize links between the academy and the labor movement.
\end{abstract}


The teach-in came at a moment when both groups face new challenges and are exploring new strategies. University faculty are confronting the loss of full-time and especially tenured positions and other threats to job security, especially for those who teach in nonvocational disciplines. Meanwhile, union membership is at a historic low, the welfare state is eroding, and "real" jobs with decent wages and security are disappearing. Organized labor, and particularly the American Federation of Labor-Congress of Industrial Organizations (AFL-CIO), has most recently addressed this challenge by undertaking membership drives and reinvigorating its role in politics. The Federation also played an important role in organizing this inaugural teach-in, with additional meetings scheduled for campuses across the country.

Academics occupied most of the positions on panels at the Columbia teach-in, but labor representatives seemed to supply more answers to the questions posed by both groups. The teach-in opened with a plenary session that attracted overflow crowds. Admission lines stretched for blocks, and much of the audience finally heard the presentation over loudspeakers on the Columbia green. Feminist writer Betty Friedan (Wilson Center for Scholars) was the first of the plenary speakers, and she opened with passion. She compared the struggles of academic and unionized labor to the women's movement in the 1960s. Each demands social justice, she declared. She urged labor and academic activists to transcend their separate visions, abandoning "identity politics" for an effective collectivism. Democratic struggle, Friedan insisted, is about seeking the "common good," where people fight for one another and their collective freedom and demands.

Philosopher Richard Rorty (University of Virginia) followed with a short talk on the history of labor unions. Union activists, he insisted, are American heroes. Their efforts on behalf of social justice, from workplace agitation to civil disobedience, have had crucial effects on the shape of American democratic culture. Unions must rebound from their declines over the last thirty years, and one way to achieve this is to engage academics as allies in retelling the histories of past struggles. Unions must regain their historical role in American politics, he claimed, for only they are likely to force politicians to confront issues of economic equality.

John Sweeney, president of the AFL-CIO, called for the labor movement to move beyond the schisms of the 1960s and 1970s. "America needs a raise," he declared-the slogan he has championed during the Federation's recent campaign to boost union membership and restore labor's political pull. Sweeney called the present moment critical for union efforts to counter the labor policies of the Republican Right, whose championship of free markets and contempt for workers' institutions have helped exacerbate the current crisis. The Right's attack on the state was an especially attractive target. "It takes a village to raise a child," he declared, and "it takes a union to get a raise." Sweeney outlined the AFL-CIO's current 
campaigns, including new lobbying efforts, voter registration, and "Union Summer," a campaign to build unions in unorganized industries and regions.

Cornel West (Harvard University) closed the plenary by reasserting the common goals of labor and the academy in the context of present politics. He praised the new initiatives of the AFL-CIO, urging listeners to understand that "we are at a fork in the road" and that "we are going to keep the radical democratic tradition alive, come what may."

Another plenary session on "The Incorporation of America" launched the second day of the teach-in, and it too attracted an overflow crowd. The plenary featured four speakers: AFL-CIO executive vice president Linda Chavez-Thompson, writer Katha Pollitt, sociologist Orlando Patterson, and Joel Rogers of the University of Wisconsin. The speakers identified a number of common themes: that the conference was timely; that the corporate sector dominates the country in entirely new ways; that virtually the entire population suffers as a result, from declines in living standards to increases in stress; and that the labor movement has a significant responsibility and opportunity to regenerate itself in resistance to the aforementioned trends. Distinctions emerged among the speakers, however. Comment included warm reception for the changes in the AFL-CIO, supportive prodding to take bigger and faster steps, and sharp criticism of the perceived inhibitions of labor leaders to break completely out of old patterns.

Patterson and Pollitt applauded the militant remarks of ChavezThompson but noted that the AFL-CIO heritage includes a legacy of discrimination against major sections of the working population. Pollitt felt that the federation must transcend traditional concepts of solidarity, going beyond unionism as such to embrace the millions devastated by welfare rollbacks. Patterson advanced the controversial proposal that the Left should recognize the deleterious effects of immigration on living standards in the United States. Rogers, an activist in the New party, reminded that organized labor has downplayed political independence in the past, a stance increasingly difficult to justify in light of both Democratic and Republican devotion to corporate goals.

Sixteen workshops filled the schedule during the second day. These explored divisions, real and imagined, within the labor movement, and the swiftly changing political and economic environments in which labor activism must now be strategized. Most workshops managed to address the role of academic intellectuals in interpreting these new conditions and building labor solidarity.

A case in point was "The Wages of 'Race': Unions and Racial Justice," a workshop that brought together historian David Roediger (whose book lent the session its title), New York University law professor Derrick Bell, Michael Eric Dyson of the University of North Carolina, and Mae Ngai of the AFL-CIO's Asian Pacific American Labor Alliance. Roediger pointed out that the prevailing notion and image of "organized labor" is "white and 
male," a serious misrepresentation. In fact, white men constitute less than half of union membership. (See Roediger's "What If Labor Were Not White and Male? Recentering Working-Class History and Reconstructing Debate on the Unions and Race," ILWCH 51 [Spring 1997]). On a similar note, Ngai observed that to many "labor" still seems to mean a white phenomenon, in the sense that Lincoln spoke of free (white) labor. Though the image is incongruous with reality, Ngai declared that the AFL-CIO leadership is primarily a white male bastion that continues to view Asian Americans as interlopers in and underminers of the work force. Bell observed with regret that the invocation of multiracial working-class solidarity continues to fall on the deaf ears of whites, mentioning the laboreconomic roots of many "race riots" in American history. The labor movement, according to Dyson, has an obligation to be understanding of and sensitive to the complexity of "blackness," insofar as many key governmental policies and social controversies involve stereotyping or exaggerated homogenization of peoples. Above all, Dyson averred, unions should be inhospitable to the latter ideas and their implications.

The discussion following formal presentations indicated that the concept of "whiteness" may not be native to the soil. From the overall tenor of the workshop, some wondered whether the presenters fully appreciated the potential of the recent AFL-CIO changes. But others pointed out that such Federation mainstays as the construction unions still limit or exclude minority workers. An inspiring feature of the workshop was the attendance of a large number of student graduates of "Union Summer," the Federation's educational organizing effort of 1996.

A workshop on "Intellectuals and the Labor Movement" featured Bob Welch (assistant to AFL-CIO president John Sweeney), journalist Paul Berman, and labor attorney Tom Geoghegan. Despite the importance of the topic, presentations occasionally lacked focus and precision. Welch suggested that the civil rights and antiwar movements, or at least the issues and emotions surrounding them, induced a schism between unions and intellectuals, and they have since tended to take opposing sides. He appealed for change, asking intellectuals to become allies and constructive critics of the labor movement. Berman expressed excitement over the potential labor-intellectual alliance, substantially agreeing with the oftrepeated claim that the successes of labor advance the interests of all. In this regard, he cited such precedents as labor's pioneering of certain New Deal programs, the participation of many unions in the civil rights movement, and the AFL-CIO's support for trade unionists once languishing behind the Iron Curtain. This last example seemed incongruous, as the historical record demonstrates that McCarthyite-Cold War requirements took precedence over genuine sympathy: Federation leaders in fact conformed to government policy at the expense of labor's independence. In an incisive presentation, Geoghegan traced the evolution of intellectual views of organized labor from the New Deal to the present. He showed that while 
men and women of learning established strong bonds with unions in the 1930 s and created sound theories in support of collective bargaining and wage increases, intellectuals today have "defaulted" on discussions of the social benefits of improvements in the status of workers. Intellectuals would stand to gain from taking a more involved and supportive position, as the strengthening of unions tends to make society more liberal and open, creating a healthier, more tolerant climate.

A handful of workshops examined the political-economic conditions facing labor organizers today and strategies for addressing them. "Labor and the Law" and "Organizing the University" each touched on labor law as a barrier to effective organizing. "Labor and Immigration" and "Work, Welfare, and the Labor Movement" examined how groups of marginalized workers-immigrants and welfare recipients-are seen both as threats and as new organizational challenges to labor. Two workshops addressed economic globalization and the chances and limitations of international labor organizing today. One, "Organizing the Global Economy," featured three AFL-CIO activists who reported on the history and contemporary experience of global organizing. Each stressed that such efforts will become increasingly crucial as firms become more internationalized. Economist William Milberg (New School for Social Research) added perspectives on the relation between globalization and international labor rights. The evergreater mobility of international capital and the spread of liberal free trade regimes have occurred even as new immigration restrictions place further limits on the mobility of labor-a disparity which not only weakens the position of laboring immigrants but that of national labor movements. The result for all workers, Milberg contended, is a downward pressure on wages, labor rights, and environmental standards, as firms and financial capital move in search of less costly regulation and labor compensation. This movement-or even its threat-serves to pressure workers to scale back their demands for wage increases and pushes governments to reduce labor and environmental regulations. The International Labor Organization defends the rights of labor in a global context but lacks enforcement capacity. Developing countries in particular resist the strengthening of international labor rights or standards, since their comparative advantage is in the supply of cheap and exploitable labor. Milberg urged US organized labor to respond to these conditions by backing the compensation of developing countries faced with stricter international labor standards, perhaps by taxing more developed beneficiaries of international trade-via, for example, the "Tobin tax" on international financial transactions.

The teach-in concluded with a final plenary on "Organizing the Unorganized," and indeed this theme suited the proceedings of the entire meeting. Whether they be US workers denied representation by organized labor (racial minorities, women, and welfare recipients) or workers in all countries whose fates are increasingly intertwined, "the unorganized" represent less a threat than a challenge to the labor movement today. It is a weighty challenge, but one which most participants chose not to regard as discour- 
aging. In "the fight for America's future," they seemed to resolve, the unorganized are better suited as allies than as enemies.

\title{
Between Classes: A Conference on Academic Labor
}

\author{
Guy Baldwin
}

New School for Social Research

\begin{abstract}
"The university works because we work!" That was the refrain at a conference on the crises facing academic labor at New York University on November 16, 1996. Faculty, graduate students, and university staff convened to report on working conditions and propose solutions to their problems as laborers in American academia. Graduate students related their efforts on many campuses to build organizations to protect their jobs as research and teaching assistants. Support staff rallied around New York University's clerical workers, whose campaign for a closed shop coincided with the conference. Adjunct faculty stressed their struggles to enter the university work force in better than casual subsistence conditions. Full-time faculty voiced concerns about threats to faculty unions, tenure, and full-time teaching positions in the university while supporting the efforts of students, adjuncts, and staff to join them in the ranks of recognized and respected university workers.
\end{abstract}

Despite the spirit of the participants, the picture presented at the conference was bleak. As the opening session affirmed, the American university is in crisis-and its workers are the first to experience its troubles. Speakers dismissed the notion that the university is a liberal bastion in a landscape of bleak workplace transformations. Instead, insisted Carol Knox (United Auto Workers), the university is "catching up" to other industries in threatening its workers' compensation and job security. David Montgomery (Yale University) went further: $\mathrm{He}$ contended that universities are leaders in the casualization of professional work. Their administrators are ardent practitioners of the "lust for privatization," responding to often-artificial budget crises not by defending needs but by whittling at jobs and academic programs. They measure success at the bottom line, not in the classroom. Juan Flores, director of the Center for Puerto Rican Studies at the City University of New York, remembered that his job once involved "building community, directing research projects, and tying them to the community." Now he mainly fights to defend diminishing resources and to distribute them as fairly as possible. He has become a "hatchet man" for the administration's downsizing schemes, he complained. Constant cri- 